\title{
A retrospective study: physicochemical properties of the flower honey from the Black Sea region of Turkey in different years
}

\author{
Gül Banu ÇİÇEK BİDECİ ${ }^{1}$ (D), Sibel KARASALİHOĞLU ${ }^{2 *}$ (D)
}

\begin{abstract}
Honey has a remarkable commercial value as a natural product for producers. This study aimed to examine the differences in the physicochemical properties of the flower honey produced in Kastamonu, a province in the Black Sea Region of Turkey, in different years to see if they changed and if the physicochemical properties met the quality standards for honey. To this end, the honey samples (Apis mellifera) produced in Kastamonu province were studied. The samples were collected from 40 producers of honey between 2016 and 2019. We carried out the quality analysis according to the Turkish Food Codex Communiqué on Honey and compared it with the EU standards. The results showed that fructose/glucose ratio, total fructose and glucose (\%), diastase (shade), proline $(\mathrm{mg} / \mathrm{kg})$, electrical conductivity $(\mathrm{ms} / \mathrm{cm}), H M F(\mathrm{mg} / \mathrm{kg})$, and acidity $(\mathrm{meq} / \mathrm{kg})$ did not change during four years while the moisture content differed significantly. In other words, the quality of the studied samples remained stable in four years. The majority of the studied honey samples obtained from the Black Sea Region of Turkey were compatible with the Turkish Food Codex Communiqué on Honey and the EU standards.
\end{abstract}

Keywords: Black Sea Region; honey; physicochemical parameters; quality; Turkey.

Practical Application: This study gives useful insights into whether the physicochemical properties and quality of flower honey differ depending on the year of production.

\section{Introduction}

Honey is consumed all over the world for therapeutic, nutritional, and medicinal purposes (Yaqub et al., 2020). Honey is a natural product of honey bees (Apis mellifera) used for different purposes since ancient times (Ajibola et al., 2012) and is produced from the nectar collected by worker bees from flowering plants, and then transformed, dehydrated, and stored in honeycombs (Krell, 1996). Honey is an excellent food supply that includes sugars, other nutrients, and phytochemicals such as vitamins, minerals, amino acids, organic acids, phenolics, and aromatic compounds (Silva et al., 2016; Singh \& Bath, 1997).

Generally, the approximate $\mathrm{pH}$ of honey is 4.0 (Ouchemoukh et al., 2007). Several physicochemical properties show the differences in the chemical composition of honey (Bogdanov et al., 1999), and its sensorial, chemical, physical, and microbiological characteristics are investigated to determine its quality. The main criteria are moisture content, ash content, electrical conductivity, diastase activity, free acidity, 5- hydroxymethyl furfuraldehyde (HMF) content, and reducing and non-reducing sugars (Gomes et al., 2010). Honey production has developed well in Turkey thanks to its geographical and climatic conditions. As an important agricultural activity, the beekeeping has a history of thousands of years in Turkey (Kahraman et al., 2010). The Black Sea Region ranks the first in terms of production. In 2016, 1,786,996 tons of honey was produced globally and Turkey ranked the second after China with 105,532 tons (Food and Agriculture Organization, 2020). Turkey has favorable conditions for honey production like climate, topographical structure, and a wide variety of plant

flora (Gül \& Pehlivan, 2018; Sari \& Ayyildiz, 2012; Tezcan et al., 2011). The appearance, nutritional value, composition, and flavor of honey are affected by its botanical origins and the geographic location of beehives (Gül \& Pehlivan, 2018; Tezcan et al., 2011).

The composition of honey can vary depending on its origin. For example, the mineral sources primarily originate from its raw materials (nectar and honeydew) and the pollen grains (Madejczyk \& Baralkiewicz, 2008; Pohl et al., 2011). Carbohydrates (glucose and fructose) account for about $80-95 \%$ of the matrix, while the total mineral content in honey should not exceed $1 \%$. The second most important content in honey is water, and its ratio depends on several environmental factors during production such as weather and humidity (Alvarez-Suarez et al., 2010; Bogdanov et al., 2008). Besides, water content affects the basic physical characteristics of honey, such as viscosity, maturity, and crystallization (Machado De-Melo et al., 2018). Viscosity of ripe honey is higher, with water content of below $22 \%$, leading to non growth of microorganisms and longer shelf life of ripe honey (Aparna \& Rajalakshmi, 1999), and significantly improving the re-ripe honey market acceptance and increasing the beekeepers' profit given the the production rate (Guo et al., 2019). It is known that fermentation is another factor that affects the honey composition when moisture exceeds $18 \%$, especially after a long storage time (Bogdanov et al., 2008). Proteins, minerals, enzymes, vitamins, organic acids, and phenolic compounds are minor components of honey (Pohl et al., 2011). Protein, enzyme, and vitamin contents of honey are obtained from the 
pollen contents and secretions of honeybees (Apis mellifera) (Draiaia et al., 2014; Krell, 1996). Honey includes a few amino acids, and proline is recognized as the major component (Serra Bonvehí \& Escolà Jordà, 1997). The acidity of honey is due to its organic acid contents generating its characteristic flavor (Krell, 1996). Hydroxymethylfurfural (HMF) is generally used to evaluate the freshness of honey as its amount is limited in freshly harvested honey. It is mainly produced from sugars degradation, basically from fructose, because it is more labile than sucrose and glucose. The amount of HMF increases during the processes of handling, extraction, and storage (Al-Farsi et al., 2018; Visquert et al., 2014).

The purpose of this study was to investigate the differences in the physicochemical properties of flower honey (Apis mellifera) produced in the Black Sea Region of Turkey between 2016 and 2019 to see if they changed over the years and if the physicochemical properties met the quality standards for honey.

\section{Materials and methods}

This research was carried out on the honey samples (Apis mellifera) produced in Kastamonu, a province in Turkey. The samples were collected from 40 producers of honey in Kastamonu, a province located in the Black Sea Region, the northern part of Turkey, between 2016 and 2019. These producers were the members of the Turkish Association of Beekeepers. The samples were collected using 200-gram glass jars every year in August. The samples were stored at room temperature in a dark place until the analyses were carried out, taking approximately one month. We carried out the quality analysis according to the Turkish Food Codex Communique on Honey and the EU standards, which included sugar content analysis (Fructose/

Table 1. The mean values of physicochemical parameters.

\begin{tabular}{ccc}
\hline Variable & Min-max & Mean $(\mathrm{SD})$ \\
\hline Fructose/glucose ratio & $0.60-1.67$ & $1.15(.24)$ \\
Total fructose and glucose (\%) & $0.73-79.00$ & $64.54(13.95)$ \\
Diastase (shade) & $0.03-85.40$ & $14.4(12.67)$ \\
Proline $(\mathrm{mg} / \mathrm{kg})$ & $9.20-1176.10$ & $464.69(218.14)$ \\
Electrical conductivity $(\mathrm{ms} / \mathrm{cm})$ & $0.06-2.52$ & $0.54(0.38)$ \\
Moisture $(\%)$ & $1.84-20.00$ & $17.32(3.91)$ \\
Hmf $(\mathrm{mg} / \mathrm{kg})$ & $7.00-37.40$ & $18.61(8.14)$ \\
Acidity $(\mathrm{meq} / \mathrm{kg})$ & $10.20-45.60$ & $24.53(9.89)$ \\
\hline
\end{tabular}

$\mathrm{SD}=$ standard deviation.
Glucose ratio, Total Fructose, and Glucose), diastase activity, proline, electrical conductivity, moisture, Hydroxymethylfurfural (HMF), and acidity (Turkey, 2012).

\subsection{Statistical analysis}

Statistical analyses were carried out using SPSS (v.23, IBM Corp., Armonk, NY). Descriptive statistics were presented in frequency (n) and percentage (\%) for the categorical variables and median with minimum and maximum values for the numeric variables. The Kolmogorov-Smirnov test was used to test the normality of the research variables. The variables with a significance level above 0.05 were accepted to be normally distributed. The t-test, Wilcox, one-way Anova, and KruskalWallis tests were used to examine the physicochemical properties of flower honey in terms of demographics variables.

\section{Results and discussion}

As can be seen in Table 1, the mean fructose/glucose ratio was found as $1.15(0.24)$, the mean total fructose and glucose (\%) as 64.54 (13.95), the mean diastase (shade) as 14.4 (12.67), the mean proline $(\mathrm{mg} / \mathrm{kg})$ as $464.69(218.14)$, the mean electrical conductivity $(\mathrm{ms} / \mathrm{cm})$ as $0.54(0.38)$, the mean moisture contents as 17.32(3.91), the mean HMF content $(\mathrm{mg} / \mathrm{kg}$ ) as $18.61(8.14)$, and the mean acidity content as 24.53(9.89).

As can be seen in Table 2, there is a statistically significant difference in moisture content ( $\mathrm{p}$-value $=.009)$ in four years while there is no statistically significant difference in the fructose/ glucose ratio, electrical conductivity $(\mathrm{ms} / \mathrm{cm})$, and the contents of total fructose and glucose (\%), diastase (shade), proline (mg/kg), $\operatorname{HMF}(\mathrm{mg} / \mathrm{kg})$, and acidity (meq $/ \mathrm{kg})$.

To estimate the mean of the samples, a confidence interval on the mean is estimated. Table 3 shows the confidence level of the mean values of the variables. The results showed that the confidence intervals of the variables were as follows: fructose/glucose ratio $(0.9-1.4),(1.08,1.26)$; total fructose and glucose $(\%)>60,(65.54$, INF); diastase (shade) $>8,(11.74, \mathrm{INF})$; proline $(\mathrm{mg} / \mathrm{kg})>300$, (406.51, INF); electrical conductivity $(\mathrm{ms} / \mathrm{cm})<0.8$, (-INF, 0.55$)$; moisture (\%)<20, (-INF, 18.29); HMF (mg/kg)<40, (-INF, 21.42); and acidity $(\mathrm{meq} / \mathrm{kg})<50,(-\mathrm{INF}, 27.17)$.

Table 3 shows that the samples met the standards for total fructose and glucose, diastase (shade), proline, electrical conductivity, moisture, $\operatorname{HMF}(\mathrm{mg} / \mathrm{kg})$, and acidity; but not for

Table 2. The difference in the physicochemical quality measures of the honey samples in over the course of 4 years $(n=40)$.

\begin{tabular}{ccc}
\hline Variable & P-value (One-Way ANOVA, Wallis) & Min-max \\
\hline Fructose/glucose ratio & 0.262 & $0.60-1.67$ \\
Total fructose and glucose (\%) & 0.923 & $0.73-79.00$ \\
Diastase (shade) & 0.668 & $0.03-85.40$ \\
Proline (mg/kg) & 0.112 & $9.20-1176.10$ \\
Electrical conductivity (ms/cm) & 0.206 & $0.06-2.52$ \\
Moisture (\%) & 0.009 & $1.84-20.00$ \\
HMF (mg/kg) & 0.099 & $7.00-37.40$ \\
Acidity (meq/kg) & 0.493 & $10.20-45.60$ \\
\hline
\end{tabular}

HMF: Hydroxymethylfurfural; Min: Minimum; Max: Maximum. 
Table 3. The confidence level of the mean values of the variables.

\begin{tabular}{ccc}
\hline Variable & Confidence level & P-Value (T-Test, Wilcox) \\
\hline Fructose/glucose ratio $(0.9-1.4)$ & $(1.08,1.26)$ & $0.4(0.97)$ \\
Total fructose and glucose $(\%)>60$ & $(65.54$, INF) & 0.000 \\
Diastase $($ shade $)>8$ & $(11.74$, INF) & 0.000 \\
Proline $(\mathrm{mg} / \mathrm{kg})>300$ & $(406.51, \mathrm{INF})$ & 0.000 \\
Electrical conductivity $(\mathrm{ms} / \mathrm{cm})<.8$ & $(-\mathrm{INF}, 0.55)$ & 0.000 \\
Moisture $(\%)<20$ & $(-\mathrm{INF}, 18.29)$ & 0.000 \\
HMF $(\mathrm{mg} / \mathrm{kg})<40$ & $(-\mathrm{INF}, 21.42)$ & 0.000 \\
Acidity $(\mathrm{meq} / \mathrm{kg})<50$ & $(-\mathrm{INF}, 27.17)$ & 0.000 \\
\hline
\end{tabular}

fructose/glucose ratio. In the current study, we investigated 40 honey samples collected from the Black Sea Region of Turkey. The findings showed that fructose/glucose ratio, total fructose and glucose (\%), diastase (shade), proline $(\mathrm{mg} / \mathrm{kg})$, electrical conductivity $(\mathrm{ms} / \mathrm{cm}), \operatorname{HMF}(\mathrm{mg} / \mathrm{kg})$, and acidity $(\mathrm{meq} / \mathrm{kg}) \mathrm{did}$ not change in four years while the moisture content was the only variable which significantly differed in four years. The quality of the studied samples remained stable over the course of four years of study. The honey samples met the quality standards for total fructose and glucose, diastase (shade), proline, electrical conductivity, moisture, HMF (mg/kg), and acidity but not for fructose/glucose ratio. Several studies revealed that differences in climate, processing, storage conditions, and maturity affect the quality and biochemical properties of honey (Silva et al., 2016). International Honey Commission proposed some quality criteria for honey, including several parameters such as moisture content, sugar content, mineral containment, acidity, electrical conductivity, and HMF. The quality and authenticity of honey are crucial for preserving the food safety and generating favorable effects on the health of consumers (Bogdanov, 2009). Honey production is regulated by the Turkish Food Codex Communiqué on Honey in Turkey, one of the world's largest honey producers. The provisions of this regulation are similar to those in the international regulations, and it has been updated according to the latest developments announced by the international authority. Several specific laboratories in Turkey have updated their standards for evaluating honey according to international and Turkish Food Codex Communiqué on Honey.

Honey is a natural and healthy product with a changing commercial value depending on its botanic and geographic origins (Trifković et al., 2017). The stability of honey against fermentation and granulation can be determined by measuring the amount of water in honey (Dyce, 1975). Saxena et al. (2010) showed that the moisture content of honey, which is one of the descriptive quality parameters, ranged from $10.5 \%$ to $18.2 \%$ for fresh honey (Saxena et al., 2010). The acceptable limit for moisture content is $20 \%$ (Kędzierska-Matysek et al., 2016). In our study, all the honey samples complied with the commonly accepted levels for moisture content. The moisture content of honey varies depending on the degree of maturity reached in the hive, the moisture content of the original plant, and the harvest season (Finola et al., 2007). Besides, the variations in moisture content can be due to the floral origins and composition of honey (Malika et al., 2005), and moisture content can vary from year to year, which is consistent with the result reached in our study that showed a variation in moisture content in 4 years. Derebaş1 et al. (2014) found that the electrical conductivity $(\mathrm{mS} / \mathrm{cm})$ of honey samples varied from 0.12 to 2.42 with a mean value of $0.48 \pm 0.03 \mathrm{mS} / \mathrm{cm}$, very similar to the mean electrical conductivity $(0.54 \mathrm{mS} / \mathrm{cm})$ found in our study. The mean electrical conductivity $(\mathrm{mS} / \mathrm{cm})$ of the honey samples in the current study was below the maximum limit determined by TFC and EU standards $(0.8 \mathrm{mS} / \mathrm{cm})$.

Honey contains a small proportion of organic acids, which occur due to aerobic and anaerobic fermentation and give a characteristic taste to honey (Tezcan et al., 2011).

In this study, the free acidity of the honey samples varied between $10.2 \mathrm{meq} / \mathrm{kg}$ and $45.6 \mathrm{meq} / \mathrm{kg}$ with a mean value of $24.53 \mathrm{meq}$ acid $/ \mathrm{kg}$. The study samples did not exceed the limit determined by TFC and EU ( $<50 \mathrm{meq}$ acid/ $/ \mathrm{kg})$, indicating that all the honey samples were fresh. Our study results are similar to those found in the studies by Gül (2008) and Yllmaz \& Küfrevioğlu (2001). The mean value obtained in our study was higher than that found by Russo Almeida (1997) (16.50 meq acid/kg) but lower than the mean value of $31.62 \mathrm{meq} \mathrm{acid} / \mathrm{kg}$ reported by Sunay (2006). Al-Khalifa \& Al-Arify (1999), Azeredo et al. (2003), and Sari \& Ayyildiz (2012) reported that the total acidity of the samples varied between $32.3 \mathrm{meq} / \mathrm{kg}$ and $72.2 \mathrm{meq} / \mathrm{kg}$, $2.8 \mathrm{meq} / \mathrm{kg}$ and $39.5 \mathrm{meq} / \mathrm{kg}$, and $16.0 \mathrm{meq} / \mathrm{kg}$ and $39.5 \mathrm{meq} / \mathrm{kg}$, respectively (Al-Khalifa \& Al-Arify, 1999; Azeredo et al., 2003; Sari \& Ayyildiz, 2012).

The acidity which is a remarkable characteristic of the flavor, associated with the maturation state of honey (Braga et al., 2020) did not change in our study over the course of 4 years. The variation of acidity among different samples which was reported in the literature may be due to the variations in floral type of plants (Küçük et al., 2007) and harvest season (Singh \& Bath, 1997). Honey is a natural product and contains a highly concentrated, complex solution of sugar. However, adulteration of honey with cheap sugar syrup is a common problem, mainly by the addition of sucrose. The addition of fructose or glucose may alter the fructose/glucose ratio (Gül \& Pehlivan, 2018; Trifković et al., 2017). In this study, the mean glucose and fructose contents of the honey samples varied between 0.73 and $79.00 \%$, which exceeded the minimum required level of $60 \%$ according to the international quality regulations. It was reported in the literature that glucose and fructose contents of honey samples varied between $49.7 \%$ and $73.5 \%$ (Al-Khalifa \& Al-Arify, 1999; Azeredo et al., 2003; Ozcan \& Olmez, 2014), which is consistent 
with our study results, showing that the samples met the standards for total fructose and glucose.

On the other hand, the fructose/glucose ratio, which indicates the crystallization of honey, was found to be between 0.60 and 1.67 with a mean value of 1.15 , which showed that the samples did not tend to crystallize faster and were less viscous ( $F / G>1.0)$. So, the honey samples did not meet the quality standard for the fructose/glucose ratio.

It is known that the composition of honey depends on not only the diversity of flowers but also some other factors such as environmental factors, harvesting climate, processing, and storage technology (Kaškonienè \& Venskutonis, 2010; OzcanSinir et al., 2020).

Diastase activity varies depending on several factors such as exposure to high temperatures and long storage periods, which inactivate diastase (Ünal \& Küplülü, 2006). In our study, there was no change in the diastase activity in four years.

Different diastase values were reported from different countries in the literature, from 10.9 to 13.9 in Brazil and from 3.3 to 13.9 in Saudi Arabia (Al-Khalifa \& Al-Arify, 1999; Azeredo et al., 2003). Sahinler et al. (2001) and Sari \& Ayyildiz (2012) reported that the diastase value of the honey samples collected from Turkey varied within the range of 1-23 and 17.9-38.5, respectively (Sahinler et al., 2001; Sari \& Ayyildiz, 2012). Diastase value should not be lower than 8 according to the legal regulation. In our study, the mean diastase values of the honey samples was found to be 14.4, which means that the samples in our study met the quality standards. We assumed that high diastase values in our study show that honey samples were not exposed to high temperature.

Previous studies reported change of protein values of honey samples between $0.33 \%$ and $1.2 \%$ (Azeredo et al., 2003; OzcanSinir et al., 2020; Ozcan \& Olmez, 2014). Honey contains low amounts of amino acids, and proline is a major component (Serra Bonvehí \& Escolà Jordà, 1997). The mean proline content of the honey samples collected from the Black Sea region of Turkey was $464.69 \mathrm{mg} / \mathrm{kg}$, which met the standard for proline content i.e. above $300 \mathrm{mg} / \mathrm{kg}$.

The HMF mean value of the honey samples was found to be $18.61 \mathrm{mg} / \mathrm{kg}$. Azeredo et al. (2003) reported that HMF values of the honey samples varied between $3.24 \mathrm{mg} / \mathrm{kg}$ and $4.12 \mathrm{mg} / \mathrm{kg}$. The internationally acknowledged regulations state that HMF content should not exceed $40 \mathrm{mg} / \mathrm{kg}$ (Aloisi, 2010), and all the honey samples in our study complied with this level. Contrary to our study results, Ünal \& Küplülü (2006) reported a HMF value of $74.51 \mathrm{mg} / \mathrm{kg}$ for the flower honey produced in Ankara, considerably higher than the international standard limit.

Enzymatic inactivation occurs during a long time heating process, and HMF is formed by fructose degradation. Moreover, exposure to high temperature for a long time can cause nutritional loss in honey (Ozcan \& Olmez, 2014). Our results showed that the honey samples collected in all years were not exposed to high temperature. HMF content is regarded as a parameter determining the freshness of honey samples because it is not found in fresh honey and increases during processing of the product (Derebaş1 et al., 2014). In our study, no variation was observed in the HMF content with passage of time. Braga et al. (2020) found higher divergence of some patterns such as HMF, moisture, and acidity as compared to the the legislation standards.

International honey standards are given in the European Honey Directive and in the Codex Alimentarius Standard for Honey (Bogdanov et al., 1999). The honey quality standards in the draft CL 1998/12-S of the Codex Alimentarius and the EU Draft 96/0114 (CNS) are as follows: moisture content $\leq 21 \mathrm{~g} / 100 \mathrm{~g}$, reducing sugars content $\geq 65 \mathrm{~g} / 100 \mathrm{~g}$, sucrose content $\leq 5 \mathrm{~g} / 100 \mathrm{~g}$, acidity $\leq 40 \mathrm{meq} / \mathrm{kg}$, diastase activity $\geq 8$, hydroxymethylfurfural content $\leq 40 \mathrm{mg} / \mathrm{kg}$, and electrical conductivity $\leq 0.8 \mathrm{mS} / \mathrm{cm}$; and honey control laboratories recommend a minimum proline content of $180 \mathrm{mg} / \mathrm{kg}$ (Bogdanov et al., 1999), which are somewhat in line with the values in the Turkish Food Codex Communiqué on Honey.

\section{Conclusion}

It was concluded that only moisture content changed significantly in four years. The quality of the samples remained stable in four years. The quality standards for honey, such as total fructose and glucose, diastase (shade), proline, electrical conductivity, moisture, HMF $(\mathrm{mg} / \mathrm{kg})$, and acidity were met; but the standard for fructose/glucose ratio was not met in the samples. Most of the honey samples obtained from the Black Sea Region of Turkey were compatible with the standards stipulated in the Turkish Food Codex Communiqué on Honey and the Codex Alimentarius Standard for Honey. The authenticity and commercial value of honey should be evaluated based on the internationally accepted regulations to protect both the consumer and the market.

\section{References}

Ajibola, A., Chamunorwa, J. P., \& Erlwanger, K. H. (2012). Nutraceutical values of naturalhoney and its contribution to human health and wealth. Nutrition \& Metabolism, 9(1), 61. http://dx.doi.org/10.1186/17437075-9-61. PMid:22716101.

Al-Farsi, M., Al-Belushi, S., Al-Amri, A., Al-Hadhrami, A., AlRusheidi, M., \& Al-Alawi, A. (2018). Quality evaluation of Omani honey. Food Chemistry, 262, 162-167. http://dx.doi.org/10.1016/j. foodchem.2018.04.104. PMid:29751904.

Al-Khalifa, A. S., \& Al-Arify, I. A. (1999). Physicochemical characteristics and pollen spectrum of some Saudi honeys. Food Chemistry, 67(1), 21-25. http://dx.doi.org/10.1016/S0308-8146(99)00096-5.

Aloisi, P. V. (2010). Determination of quality chemical parameters of honey from Chubut (Argentinean Patagonia). Chilean Journal of Agricultural Research, 70(4), 640-645. http://dx.doi.org/10.4067/ S0718-58392010000400015.

Alvarez-Suarez, J. M., Tulipani, S., Romandini, S., Bertoli, E., \& Battino, M. (2010). Contribution of honey in nutrition and human health: a review. Mediterranean Journal of Nutrition and Metabolism, 3(1), 15-23. http://dx.doi.org/10.1007/s12349-009-0051-6.

Aparna, A. R., \& Rajalakshmi, D. (1999). Honey-its characteristics, sensory aspects, and applications. Food Reviews International, 15(4), 455-471. http://dx.doi.org/10.1080/87559129909541199.

Azeredo, L. C., Azeredo, M. A. A., Souza, S. R., \& Dutra, V. M. L. (2003). Protein contents and physicochemical properties in honey 
samples of Apis mellifera of different floral origins. Food Chemistry, 80(2), 249-254. http://dx.doi.org/10.1016/S0308-8146(02)00261-3.

Bogdanov, S. (2009). Harmonised methods of the International Honey Commission (pp. 1-63). İstanbul: IHC.

Bogdanov, S., Jurendic, T., Sieber, R., \& Gallmann, P. (2008). Honey for nutrition and health: a review. Journal of the American College of Nutrition, 27(6), 677-689. http://dx.doi.org/10.1080/07315724.2 008.10719745. PMid:19155427.

Bogdanov, S., Lüllmann, C., \& Martin, P. (1999). Honey quality, methods of analysis and international regulatory standards: review of the work of the International Honey Commission. Mitteilungen aus Lebensmitteluntersuchung und Hygiene, 90(1), 108-125.

Braga, D. C., Liberato, M. D. C. T. C., Lima, V. L. F., \& Araújo, J. A. M. No. (2020). Analytical study of the physicochemical characteristics from Melipona subnitida D. honey in adequation to Brazilian law. Food Science and Technology, 40(Suppl. 1), 217-221. http://dx.doi.org/10.1590/fst.08919.

Derebaşı, E., Bulut, G., Col, M., Güney, F., Yaşar, N., \& Ertürk, Ö. (2014). Physicochemical and residue analysis of honey from Black Sea region of Turkey. Fresenius Environmental Bulletin, 23(1), 10-17.

Draiaia, R., Rezki, A. R., Khalil, B. n., \& Chefrour, E. (2014). Quality of some Algerian honey: study of botanical and some physicochemical parameters. Middle East Journal of Scientific Research, 22(9), 1363-1371.

Dyce, E. J. (1975). Producing finely granulated or creamed honey. In E. Crane (Ed.), Honey: a comprehensive survey (pp. 293-306). London: Heinemann.

Finola, M. S., Lasagno, M. C., \& Marioli, J. M. (2007). Microbiological and chemical characterization of honeys from central Argentina. Food Chemistry, 100(4), 1649-1653. http://dx.doi.org/10.1016/j. foodchem.2005.12.046.

Food and Agriculture Organization - FAO, FAOSTAT Livestock. (2020). Primary production of honey, natural: top 10 producers. Rome: FAO.

Gomes, S., Dias, L. G., Moreira, L. L., Rodrigues, P., \& Estevinho, L. (2010). Physicochemical, microbiological and antimicrobial properties of commercial honeys from Portugal. Food and Chemical Toxicology, 48(2), 544-548. http://dx.doi.org/10.1016/j.fct.2009.11.029. PMid:19909782.

Gül, A. (2008). Türkiye'de üretilen bazı balların yapısal özelliklerinin gıda güvenliği bakımından araştırılması (Doktora tezi). Fen Bilimleri Enstitüsü, Hatay.

Gül, A., \& Pehlivan, T. (2018). Antioxidant activities of some monofloral honey types produced across Turkey. Saudi Journal of Biological Sciences, 25(6), 1056-1065. http://dx.doi.org/10.1016/j.sjbs.2018.02.011. PMid:30174502.

Guo, N., Wang, Q., Shen, L., Wang, L., \& Zhao, Y. (2019). An effective and economic method to produce re-ripe honey with honeybee colonies. Food Science and Technology, 39(Suppl. 2), 510-516. http:// dx.doi.org/10.1590/fst.23618.

Kahraman, T., Buyukunal, S. K., Vural, A., \& Altunatmaz, S. S. (2010). Physico-chemical properties in honey from different regions of Turkey. Food Chemistry, 123(1), 41-44. http://dx.doi.org/10.1016/j. foodchem.2010.03.123.

Kaškonienè, V., \& Venskutonis, P. R. (2010). Floral markers in honey of various botanical and geographic origins: a review. Comprehensive Reviews in Food Science and Food Safety, 9(6), 620-634. http://dx.doi. org/10.1111/j.1541-4337.2010.00130.x.

Kędzierska-Matysek, M., Florek, M., Wolanciuk, A., \& Skałecki, P. (2016). Effect of freezing and room temperatures storage for 18 months on quality of raw rapeseed honey (Brassica napus). Journal of Food Science and Technology, 53(8), 3349-3355. http://dx.doi. org/10.1007/s13197-016-2313-x. PMid:27784929.
Krell, R. (1996). Value-added products from beekeeping (FAO Agricultural Services Bulletin, No. 124). Rome: Food and Agriculture Organization of the United Nations.

Küçük, M., Kolaylı, S., Karaoğlu, Ş., Ulusoy, E., Baltacı, C., \& Candan, F. (2007). Biological activities and chemical composition of three honeys of different types from Anatolia. Food Chemistry, 100(2), 526-534. http://dx.doi.org/10.1016/j.foodchem.2005.10.010.

Machado De-Melo, A. A., Almeida-Muradian, L. B., Sancho, M. T., \& Pascual-Maté, A. (2018). Composition and properties of Apis mellifera honey: a review. Journal of Apicultural Research, 57(1), 5-37. http://dx.doi.org/10.1080/00218839.2017.1338444.

Madejczyk, M., \& Baralkiewicz, D. (2008). Characterization of Polish rape and honeydew honey according to their mineral contents using ICP-MS and F-AAS/AES. Analytica Chimica Acta, 617(1-2), 11-17. http://dx.doi.org/10.1016/j.aca.2008.01.038. PMid:18486635.

Malika, N., Mohamed, F., \& Chakib, E. A. (2005). Microbiological and physicochemical properties of Moroccan honey. International Journal of Agriculture and Biology, 7(5), 773-776.

Ouchemoukh, S., Louaileche, H., \& Schweitzer, P. (2007). Physicochemical characteristics and pollen spectrum of some Algerian honeys. Food Control, 18(1), 52-58. http://dx.doi.org/10.1016/j.foodcont.2005.08.007.

Ozcan, M. M., \& Olmez, C. (2014). Some qualitative properties of different monofloral honeys. Food Chemistry, 163, 212-218. http:// dx.doi.org/10.1016/j.foodchem.2014.04.072. PMid:24912718.

Ozcan-Sinir, G., Copur, O. U., \& Barringer, S. A. (2020). Botanical and geographical origin of Turkish honeys by selected-ion flow-tube mass spectrometry and chemometrics. Journal of the Science of Food and Agriculture, 100(5), 2198-2207. http://dx.doi.org/10.1002/ jsfa.10244. PMid:31901138.

Pohl, P., Sergiel, I., \& Prusisz, B. (2011). Direct analysis of honey for the total content of $\mathrm{Zn}$ and its fractionation forms by means of flame atomic absorption spectrometry with solid phase extraction and ultrafiltration approaches. Food Chemistry, 125(4), 1504-1509. http://dx.doi.org/10.1016/j.foodchem.2010.10.077.

Russo Almeida, P. A. (1997). Honey of transmontane Terra Quente: some chemical parameters of honey from transmontane Terra Quente. Apicultor, 5, 29-35.

Sahinler, N., Sahinler, S., \& Gül, A. (2001). Hatay yöresi ballarının bilesimi ve biyokimyasal analizi. M.K.Ü Ziraat Fakultesi Dergisi, 6, 93-108.

Sari, E., \& Ayyildiz, N. (2012). Biological activities and some physicochemical properties of sunflower honeys collected from the Thrace region of Turkey. Pakistan Journal of Biological Sciences: PJBS, 15(23), 11021110. http://dx.doi.org/10.3923/pjbs.2012.1102.1110. PMid:24261112.

Saxena, S., Gautam, S., \& Sharma, A. (2010). Physical, biochemical and antioxidant properties of some Indian honeys. Food Chemistry, 118(2), 391-397. http://dx.doi.org/10.1016/j.foodchem.2009.05.001.

Serra Bonvehí, J., \& Escolà Jordà, R. (1997). Nutrient composition and microbiological quality of honeybee-collected pollen in Spain. Journal of Agricultural and Food Chemistry, 45(3), 725-732. http:// dx.doi.org/10.1021/jf960265q.

Silva, P. M., Gauche, C., Gonzaga, L. V., Costa, A. C. O., \& Fett, R. (2016). Honey: chemical composition, stability and authenticity. Food Chemistry, 196, 309-323. http://dx.doi.org/10.1016/j. foodchem.2015.09.051. PMid:26593496.

Singh, N., \& Bath, P. K. (1997). Quality evaluation of different types of Indian honey. Food Chemistry, 58(1), 129-133. http://dx.doi. org/10.1016/S0308-8146(96)00231-2.

Sunay, A. E. (2006). Problem of antibiotic residues in honey. Uludag Bee Journal, 4, 143-148. 
Tezcan, F., Kolayli, S., Ulusoy, H. S. E., \& Erim, F. B. (2011). Evaluation of organic acid, saccharide composition and antioxidant properties of some authentic Turkish honeys. Journal of Food and Nutrition Research, 50, 33-40.

Trifković, J., Andrić, F., Ristivojević, P., Guzelmeric, E., \& Yesilada, E. (2017). Analytical methods in tracing honey authenticity. Journal of AOAC International, 100(4), 827-839. http://dx.doi.org/10.5740/ jaoacint.17-0142. PMid:28527183.

Turkey, Ministry of Agriculture and Forestry. (2012, July 27). Turkish food codex communiqué on honey-2012/58. Official Journal.

Ünal, C., \& Küplülü, Ö. (2006). Chemical quality of strained honey consumed in Ankara. Veterinary Journal of Ankara University, 53, 1-4.
Visquert, M., Vargas, M., \& Escriche, I. (2014). Effect of postharvest storage conditions on the colour and freshness parameters of raw honey. International Journal of Food Science \& Technology, 49(1), 181-187. http://dx.doi.org/10.1111/ijfs.12296.

Yaqub, G., Khalid, M., Ikram, A., \& Sohail, A. (2020). Monitoring and risk assessment due to presence of metals and pesticides residues in honey samples from the major honey producing forest belts and different brands. Food Science and Technology, 40(Suppl. 1), 331-335. http://dx.doi.org/10.1590/fst.01919.

Yilmaz, H., \& Küfrevioğlu, Ö. İ. (2001). Composition of honeys collected from Eastern and South-Eastern Anatolia and effect of storage on hydroxymethylfurfural content and diastase activity. Turkish Journal of Agriculture and Forestry, 25(5), 347-349. 